\title{
Applications and Rate-limiting Parameters of Aerobic Denitrification
}

\author{
Huiying Li ${ }^{1, ~ a}$, Wenxiang Wang ${ }^{1, b}$, Bo Yan ${ }^{2}$ \\ ${ }^{1}$ Deparment of Heavy Metal Pollution Control and Comprehensive Utilization of Resources Key Laboratory, \\ Guangdong Polytechnic of Environmental Protection Engineering, Foshan, 528216, China \\ ${ }^{2}$ State Key Laboratory of Organic Geochemistry, Guangdong Key Laboratory of Environmental Protection \\ and Resources Utilization, Guangzhou Institute of Geochemistry, Chinese Academy of Science, Guangzhou \\ 510640) \\ aemail: 125390881@qq.com, bemail: 66450477@qq.com
}

Keywords: Aerobic denitrification; Aerobic denitrifiers; Rate-limiting parameters

\begin{abstract}
The presence of nitrogenous substances in wastewater discharges has attracted attention because of the role of nitrogen in eutrophication of receiving waters. Nitrogen removal is an important aspect of present day wastewater treatment processes. However, conventional nitrification-denitrification treatment is uneconomical and difficult to operate due to extremely slow nitrification and the necessity for separate nitrification and denitrification reactors. Recently, several novel aerobic denitrification processes have been developed for cost-effective biological nitrogen removal. These processes can reduce inorganic nitrate compounds to harmless nitrogen gas. Applications of aerobic denitrifiers in wastewater processing and NOx treatment are summarized. The effect of the $\mathrm{C} / \mathrm{N}$ ratio and dissolved oxygen concentration on the denitrification activity are noted.
\end{abstract}

\section{Introduction}

In recent years, with the increase of industrial and agricultural pollution and soil erosion, nitrogen pollution has become increasingly serious. It will cause eutrophication of water bodies and may also cause harm to humans and animals. The biological nitrogen removal method is highly efficient and low-cost, and has become one of the economical and effective methods for sewage denitrification treatment. Biological nitrogen removal includes aerobic nitrification and anoxic denitrification. Traditional theory believes that the bacterial denitrification process is a strict anaerobic process. Most denitrifying bacteria still use dissolved oxygen as the final electron acceptor under low dissolved oxygen $(0.1 \mathrm{mg} / \mathrm{L})$ conditions, and nitrate and nitrite do not replenish, thus preventing the denitrification reaction. However, recent studies have shown that denitrification also exists under aerobic conditions. Since the first separation of aerobic denitrifying bacteria in the sulfur removal and denitrification treatment systems by Robertson et al. ${ }^{[1]}$ in the 1980 s, domestic and foreign scholars have successively isolated some aerobic denitrifying bacteria, aerobic denitrification. The reaction is beneficial to realize the simultaneous nitrification and denitrification process in the same bioreactor, which can greatly reduce the difficulty of biological treatment operation and operation cost, and shorten the treatment cycle. At present, there are many research reports on the theory and technology of biological nitrogen removal in polluted environment ${ }^{[2]}$, but there are not many studies on the application and influencing factors of aerobic denitrifying bacteria in environmental management. This article will study and explore it.

\section{Applications of Aerobic Denitrification}

\subsection{Wastewater}

In wastewater treatment, the nitrification step is often a bottleneck. The residence time in the nitrification unit is mainly determined by slow-growing nitrifiers ${ }^{[3-4]}$. In view of its higher growth rate and ability to convert ammonia to nitrogen gas, use of aerobic denitrifiers provides an attractive 
alternative in wastewater treatment to simultaneously remove two priority pollutants viz. carbon and nitrogen. Aerobic denitrification has distinct advantages over traditional anoxic denitrification as follows ${ }^{[5-7]}$ : (i) simplicity and low construction cost for simultaneous nitrification and denitrification in the one reactor; (ii) accelerated nitrification and denitrification, because the nitrifying products $\mathrm{NO}_{2}{ }^{-}-\mathrm{N}$ and $\mathrm{NO}_{3}{ }^{-}-\mathrm{N}$ can be the denitrifying reactant; (iii) less buffering is needed, as alkalinity generated during denitrification can partly compensate for the alkalinity destroyed in nitrification; (vi) no carbon removal step required before nitrification, no external carbon source needed for denitrification; (v) no acclimatization problems, as faced in a single stage oxic-anoxic system.

In a resent study ${ }^{[8-9]}$, $T$. pantotropha mixed with activated sludge was shown to aerobically denitrify synthetic wastewater having $\mathrm{NO}_{3}{ }^{-} \mathrm{N}$ concentrations up to $425 \mathrm{mg} / \mathrm{L}$. The hydraulic retention times were 0.5 and 1 day; solids retention time varied between 2 and 8 days. $\mathrm{A} \mathrm{NO}_{3}{ }^{-}-\mathrm{N}$ removal efficiency of $75-85 \%$ was obtained. A study by Gupta et al. ${ }^{[10]}$ involved the growth of a mixed culture bacterial biofilm containing $T$. pantotropha in a rotating biological contactor (RBC) for the treatment of different strengths of a simulated domestic wastewater. High nitrification rates of $0.47-1.85 \mathrm{~g} \mathrm{~N} / \mathrm{m}^{2} / \mathrm{d}$ were obtained for loading rates of $0.69-3.35 \mathrm{~g} \mathrm{~N} / \mathrm{m}^{2} / \mathrm{d}$ despite concurrent high organic loading rates of $6.9-32 \mathrm{~g} \mathrm{COD} \mathrm{g} \mathrm{N} / \mathrm{m}^{2} / \mathrm{d}$. The nitrogen removal was $18-72 \%$. The system was able to achieve effluent standards for both organics and nitrogen under such high loading rates, which are conventionally used to design treatment facilities for only organics removal. Step-feeding resulted in achieving the effluent at much higher loading rates. The biofilm showed better shock-loading characteristics than autotrophic biofilms used for nitrification.

Kshirsagar et al. ${ }^{[11]}$ demonstrated the feasibility of combining nitrification and denitrification in a single aerobic reactor by inoculating activated nitrifying sludge with $T$. pantotropha. In another study by Kshirsagar ${ }^{[11]}$, two identical oxidation ditches were utilized to compare nitrogen removal from a simulated fertilizer industry wastewater using flocculated algal-bacterial systems with and without $T$. pantotropha. The wastewater had a TKN concentration of $790 \mathrm{mg} / \mathrm{L}$. In the system with T. pantotropha, the TKN removal (nitrification) and nitrogen removal (denitrification) efficiencies were approximately 10 and $20 \%$ higher than the other system under similar operating conditions. This confirmed the importance of the heterotrophic nitrification and aerobic denitrification contributions of T. pantotropha.

Hung et al. ${ }^{[12]}$ isolated a bacterium Alcaligenes faecalis strain No.4, which has heterotrophic nitrification and aerobic denitrification abilities, which was used to treat piggery wastewater containing high strength ammonium under aerobic conditions. In a continuous experiment using a solids-free wastewater (SFW) mixed with feces, almost all of the $2000 \mathrm{NH}_{4}{ }^{+}-\mathrm{N} \mathrm{mg} / \mathrm{L}$ and 12,000 COD $\mathrm{mg} / \mathrm{L}$ in the wastewater was removed and the ammonium removal rate was approximately 30mg N/L/h, which was 5-10 times higher than the rates achieved by other bacteria with the same abilities. Denitrification was more than $65 \%$ of $\mathrm{NH}_{4}{ }^{+}-\mathrm{N}$, indicating that strain No. 4 exhibited its heterotrophic nitrification and aerobic denitrification abilities in this wastewater. Oguz ${ }^{[13]}$ stated that in a batch and completely mixed reactor with activated sludge, $0.07 \mathrm{~kg} \mathrm{~N} / \mathrm{m}^{3} /$ day of nitrogen conversion and 56.7\% removal rate were observed, producing almost equivalent amounts of $\mathrm{N}_{2}$ and $\mathrm{N}_{2} \mathrm{O}$. An experimental study was carried out on the aerobic denitrification in surface water treatment, and good results were achieved under high hydraulic loading, with nitrogen removal of $20 \%-30 \%{ }^{[14]}$.

\subsection{NOx Emissions}

The burning of fossil fuels is a major source of atmospheric nitrogen oxides (NOx). Although low levels of nitrous oxide $\left(\mathrm{N}_{2} \mathrm{O}\right)$ are emitted, nitric oxide (NO) and nitrogen dioxide $\left(\mathrm{NO}_{2}\right)$ are the major NOx components released during combustion processes ${ }^{[15]}$. Emissions of NOx in China have undergone an almost exponential increase over the past decade. In the year 2004, NOx emissions from its electricity industry alone exceeded 6.65 million tons. If recent trends continue, NOx emissions could reach 7.13 million tons in $2010^{[16]}$. Nitrogen oxides are hazardous pollutants which adversely affect human health; exposure to $\mathrm{NO}_{2}$ at concentrations of $100 \mathrm{ppm}$ or greater can result 
in respiratory distress or death. Nitrogen oxides are also detrimental to the environment. In the atmosphere, $\mathrm{NO}$ and $\mathrm{NO}_{2}$ react with moisture in the air to form nitrous acid, which in turn, leads to the formation of acid rain. In addition, NOx contributes to stratospheric ozone depletion and global warming $^{[17-18]}$. Traditional controls, such as selective catalytic reduction and selective non-catalytic reduction, are used to limit power plant NOx emissions. Although this is an effective technique, both processes require high temperatures or the use of catalysts, creating high installation and maintenance costs. This cost is prohibitive for large-scale treatment of air containing low to moderate concentrations of $\mathrm{NOx}^{[19]}$. Biofiltration, a biological process, may offer an alternative technology to remediate emissions containing NOx.

Denitrifiers have the ability to reduce NOx under limited oxygen conditions. The reductive process occurs in the following simplified order ${ }^{[20]}: \quad \mathrm{NO}_{3}{ }^{-} \rightarrow \mathrm{NO}_{2}{ }^{-} \rightarrow \mathrm{NO} \rightarrow \mathrm{N}_{2} \mathrm{O} \rightarrow \mathrm{N}_{2}$. Thus denitrifying bacteria use toxic nitrogen oxides to produce environmentally benign nitrogen gas. Some attempts at this sequential reaction have been made, such as NOx removal by biofiltration under anaerobic conditions ${ }^{[20-22]}$, or by algae culture under light exposure ${ }^{[23-24]}$. However, concentrations of up to $10 \%$ oxygen in flue gas inhibit the removal of NOx compounds by typical denitrifying bacteria ${ }^{[19]}$. Removal efficiency (RE) greater than $50 \%$ occurs in an oxygen-free environment, but was reduced to less than $20 \%$ when $2 \%$ oxygen was introduced into the gasstream $^{[25]}$. Both anaerobic and light-exposed systems for the removal of NOx are extremely difficult to construct and operate outdoors. To overcome this problem, novel aerobic denitrifying bacteria are required that can be used to construct aerobic denitrifying processes. Patureau et al. ${ }^{[26]}$ have shown that there was no specific natural ecological niche for aerobic denitrifiers but as soon as selective pressure, such as alternating aeration, was applied, this flexible nitrate-oxygen metabolism was amplified. Under specific conditions, aerobic denitrification does occur and might have evolved several times ${ }^{[27]}$.

Okuno et al. ${ }^{[28]}$ investigated the possibility of aerobic removal of NOx using a laboratory-scale biofilter packed with soil. This biofilter system will be applicable to the treatment of NOx gas emitted in tunnels or underground parking areas, by passing the gas through the packed soil. The removal efficiency of $\mathrm{NO}_{2}$ by soil was almost $100 \%$, and the removal efficiency of $\mathrm{NO}$ was $60 \%$ on average and $86 \%$ at maximum. However, the removal efficiency of $\mathrm{NO}$ in the sterilized soil was only $20 \%$, suggesting that NO in soil was removed microbiologically under aerobic conditions. Chung and Huang ${ }^{[29]}$ were successful in treating ammonia in air by an immobilized Nitrosomonas europaea biofilter with removal efficiencies greater than $97 \%$. Du Plessis et al. ${ }^{[30]}$ were successful in removing an NO concentration of $60 \mathrm{ppm}$ at an EBRT of $3 \mathrm{~min}$ in an aerobic toluene treating reactor. Chou and Lin ${ }^{[31]}$ demonstrated the suitability of a biotrickling filter for the removal of NO.

Our group has been working in this area for long years. Jiang et al. ${ }^{[32]}$ developed an effective biotrickling filter (BF) system to inoculate a newly isolated strain of Pseudomonas putida SB1 for the effective treatment of nitric oxide (NO) from a synthetic gas-stream. The SB1 showed a denitrifying capability of $95 \%$ nitrate removal rate over a 24 h period in an aerobic environment, with no nitrite accumulation. The BF system was able to consistently remove 82.9-94.2\% NO when the inlet NO was $400 \mathrm{ppm}$ in an enriched oxygen stream of 2-20\%. The oxygen had no negative effect on the aerobic denitrifier SB1, but rather enhanced the total efficiency in part by chemical oxidation and in part by the activities of the strain. $79.3 \%$ of the total NO removal can be attributed to bio-denitrifying at $20 \%$ oxygen, and most chemical oxidation occurred concurrently. Overall, the study demonstrates that NO removal by an aerobic denitrifying process in BF is feasible for a flue gas. 


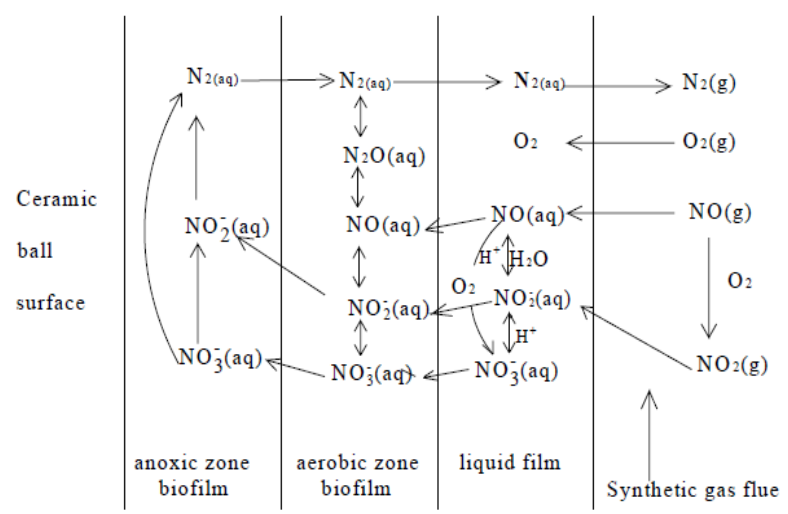

Figure.1 Possible pathway of NOx possible transformations in Aerobic Biofilter System ${ }^{\text {[32] }}$

The mechanism of nitrogen loss can be imagined as absorption, where nitrification was the pretreatment for denitrification, whereby $\mathrm{NO}(\mathrm{g})$ was converted to $\mathrm{NO}_{2}(\mathrm{~g}), \mathrm{NO}_{2}{ }^{-}(\mathrm{aq})$, and $\mathrm{NO}_{3}{ }^{-}$(aq). Almost all of the $\mathrm{NO}_{2}(\mathrm{~g}), \mathrm{NO}_{2}{ }^{-}(\mathrm{aq})$, and $\mathrm{NO}_{3}{ }^{-}(\mathrm{aq})$ were converted to $\mathrm{N}_{2}$ and biomass during denitrification. The possible pathways of NOx removal which may occur in the biofilter system are shown in Figure.1.

\subsection{Other applications}

Aquaculture has been developing rapidly. Large quantities of waste water are produced in aquaculture and are often discharged into receiving waters with little or no treatment, with effects such as eutrophication and red tides. Ammonia is the most important contaminant in aquaculture waste water and it is difficult to remove from the water. Physical methods such as foam separation and filtration are popular. These methods can remove suspended particles effectively but cannot reduce the concentration of soluble matter, including ammonia. Yu et al. ${ }^{[3]}$ isolated a bacterium, Bacillus W2, from fishpond which is highly effective in denitrification under aerobic conditions. It can eliminate $97 \%$ of the nitrogen at dissolved oxygen of $2 \mathrm{mg} / \mathrm{L}$. Even when the DO is as high as $5 \mathrm{mg} / \mathrm{L}$, denitrification still occurs, with more than 85\% of the nitrogen removed. Under aerobic conditions, when the bacterial concentration was $1000 \mathrm{~A} / \mathrm{mL}$, it still could bring highly effective denitrification into play in a natural water body at $1 \mathrm{mg} / \mathrm{L}$ nitrite.

In particular environments, aerobic denitrifiers may offer several potential advantages for removing toxic or refractory pollutants ${ }^{[34]}$. An aerobic, nitrate-respiring bacterium which can degrade phenol under aerobic conditions was isolated by Seung et al. ${ }^{[35]}$ and identified as Alcaligenes sp. Under microaerobic culture, the maximum concentration for phenol degradation was $0.29 \mathrm{mM}$ in the presence of nitrate and $\mathrm{O}_{2}$ but only $0.16 \mathrm{mM}$ in the presence of $\mathrm{O}_{2}$ alone.

\section{Rate-Limiting Parameters of Aerobic Denitrification}

The rate-limiting parameters in aerobic denitrification include the dissolved oxygen concentration, the substrates $\mathrm{C} / \mathrm{N}$ ratio, temperature and $\mathrm{pH}^{[36-37]}$ Among these parameters, dissolved oxygen concentration and organic carbon concentration are suggested as the two major factors affecting the denitrification reaction.

\subsection{Carbon and nitrogen ratio(C/N)}

Several studies have demonstrated that, within an optimal range, the higher the carbon concentration as an energy source, the faster the denitrification reaction of the aerobic denitrifier. Each aerobic denitrifier has an optimum $\mathrm{C} / \mathrm{N}$ ratio.

An aerobic denitrifier was newly isolated from soil and its denitrification activity under different $\mathrm{C} / \mathrm{N}$ ratios was investigated. The isolate was identified as Pseudomonas putida AD-21. Increasing the $\mathrm{C} / \mathrm{N}$ ratio increased the nitrate removal rate. The optimal $\mathrm{C} / \mathrm{N}$ ratio was 8 with a maximum nitrate removal rate of $255 \mathrm{mg} / \mathrm{L} / \mathrm{h}$ and a nitrate removal efficiency of $95.9 \%{ }^{[38]}$.In a study by Joong et al. ${ }^{[39]}$, twenty-four Bacillus strains predominantly outgrown in a night soil treatment system were 
isolated and characterized. Maximum removal of $\mathrm{NH}_{4}{ }^{+}-\mathrm{N}$ and cell production by the isolates occurred with a $\mathrm{C} / \mathrm{N}$ ratio of 8 . Five dominant isolates were identified to be species of Bacillus cereus.

It is essential that the carbon can be successfully exploited in the denitrification pathway. Not only does the bacterium need a carbon source for its cell growth, but it also requires organic compounds as its energy source for denitrification. If the carbon source is limited, there is insufficient electron flow to provide energy for cell growth, and the denitrification rate may slow. However, when the supply of carbon is higher than the cells demand, the denitrification rate shows a very limited increase with a further increase in carbon.

\subsection{Dissolved oxygen concentration (DO)}

DO is another important factor that affects denitrification efficiency. Different enzymes and species in the denitrification pathway in aerobic denitrifiers respond to different concentrations of oxygen. Pseudomonas sp. has a maximum tolerance for dissolved oxygen concentration below 4 $\mathrm{mg} / \mathrm{L}$; nitrate reductase might not, however, be inhibited. In addition, nitrite reductase cannot complete the reduction reaction when the dissolved oxygen concentration is below $2 \mathrm{mg} / \mathrm{L}^{[40]}$. Huang et al. ${ }^{[37]}$ found that C.diversus may tolerate a dissolved oxygen concentration up to $5 \mathrm{mg} / \mathrm{L}$. The $C$. diversus strain in their study has a higher tolerance for dissolved oxygen than other aerobic denitrifiers. One explanation is that an insufficient dissolved oxygen concentration may cause the reduction rate of nitrate to generate a "resting" phenomenon, leading to a decrease in co-respiration. Second, as explained by Schulp and Stouthamer ${ }^{[41]}$.Some bacterial nitrate reductase may gradually be inactivated under aerobic conditions.

\section{Prospects}

Although the current research on aerobic denitrification has achieved a series of important results, there are still some shortcomings: (1) Most of the filtered aerobic denitrifying bacteria have low nitrogen removal efficiency.Generally, it has denitrification activity when the dissolved oxygen concentration is low.(2) At present, most of the research on aerobic denitrification is still in the laboratory stage, and the actual engineering application is less. Therefore, the future research focus can be appropriately placed on the screening and domestication of aerobic denitrifying bacteria, and modern molecular biology techniques can be used to construct efficient genetic engineering bacteria. At the same time, the mechanism of denitrification of aerobic denitrifying bacteria should be strengthened. In summary, the discovery of aerobic denitrification is a major complement to the traditional biological nitrogen removal theory, and the disclosure of its mechanism of action contributes to the development of new nitrogen removal technologies.

\section{Acknowledgements}

2017 Guangdong Province University Innovation Team Project (No. 2017GKCXTD004)

Scientific research of Guangzhou science and Technology Bureau (No. 20160702003)

\section{References}

[1] Robertson L A,Kuenen J G. Thiosphaera pantotropha gen.nov.sp.nov.,a facultatively anaerobic, facultatively autotrophic sulphur bacterium[J]. Journal of General Microbiology, 1983, 129( 9) : 2847-2855.

[2] Chen P Z,Li J,Li Q X,et al. Simultaneous heterotrophic nitrification and aerobic denitrification by bacterium Rhodococcus sp. CPZ24[J]. Bioresource Technology,2012,116: 266-270

[3] Jetten MSM, Logemann S, Muyzer G, Robertson LA, et al. 1997. Novel principles in the microbial conversion of nitrogen compounds. Ant Leeuwenhoek 71: 75-93.

[4] Muller A, Wentzel MC, Loewenthal RE, et al. 2003. Heterotroph anoxic yield in anoxic aerobic 
activated sludge system treating municipal wastewater. Water Res 37: 2435-2441.

[5] Wang P, Li XT, Xiang MF, et al. 2007. Characterization of efficient aerobic denitrifiers isolated from two different sequencing batch reactors by 16S-rRNA analysis. J Biosci Bioeng 103(6): 563-567.

[6] Hippen A, Baumgarten G, Rosenwinkel KH 1997. Aerobic denitrification: A new experience in the treatment of wastewater. Water Sci Technol 35(9): 111-120.

[7] Li P, Zhang S, Liu DL 2005. Study progress of bacterial aerobic denitrification. Journal of Microbiology (in Chinese, with English abstract) 25(1): 60-64.

[8] Gupta AB, Kshirsagar M and Gupta SK. 1992. Dissimilatory nitrate reduction under aerobic conditions by T. pantotropha mixed activated sludge. Int J Environ Studies 40:100.

[9] Kshirsagar M, Gupta AB and Gupta SK. 1994. Aerobic denitrification studies on activated sludge mixed with Thiosphaera pantotropha. Environ Technol 16: 35-43.

[10] Gupta SK, Raja S and Gupta AB 1994. Simultaneous nitrification and denitrification in RBC. Environ Technol 15: 143-150.

[11] Kshirsagar M. 1995.Biological nitrification-denitrification of high strength nitrogenous wastewater by flocculating algal-bacterial system in oxidation ditch. Doctor Dissertation. Bombay: Indian Institute of Technology.

[12] Hung SJ, Mitsuyo H, Makoto S 2006. Piggery wastewater treatment using Alcaligenes faecalis strain No. 4 with heterotrophic nitrification and aerobic denitrification. Water Res 40: 3029-3036.

[13] Oguz M 2004. Volatile fatty acid effects on nitrite removal and nitrate formation during activated sludge treatment. Doctoral Dissertation, Knoxville: University of Tennessee.

[14] Xie SG, Zhang XJ, Wang ZS 2002. Aerobic denitrification in surface water treatment. China Water and Wastewater (in Chinese, with English abstract), 18(3) : 7-9.

[15] Rasmussen RA and Khalil MAK 1986. Atmospheric trace gases: Trends and distributions over the last decade. Science 232: 1623-1624.

[16] Zhu FH. 2006. Electric power industry development and environmental protect. Electric Power Environ Protect 22: 1-7.

[17] Anderson IC, Levine JS 1986. Relative rates of nitric oxide and nitrous oxide production by nitrifiers, denitrifiers, and nitrate respirers. Appl Environ Microbiol 51: 938-945.

[18] Ye RW, Averill BA and Tiedje JM 1994. Denitrification: Production and consumption of nitric oxide. Appl Environ Microbiol 60: 1053-1058.

[19] Jin Y, Veiga VM, Kennes C 2005. Bioprocesses for the removal of nitrogen oxides from polluted air, J Chem Technol Biotechnol 80: 483-494.

[20] Barnes JM, Apel WA, Barrett KB 1995. Removal of nitrogen oxides from gas streams using biofiltration, J Hazard Mater 41: 315-326.

[21] Apel WA, Turick CE 1993. The use of denitrifying bacteria for the removal of nitrogen oxides from combustion gases. Fuel 72: 1715-1718.

[22] Shanmugasundram R, Lee CM, Sublette KL. Reduction of nitric oxide by denitrifying bacteria. Appl Biochem Biotech 1993, 39: 727-737.

[23] Yoshihara K, Nagase H, Eguchi K, et al. 1996. Biological elimination of nitric oxide and carbon dioxide from flue gas by marine microalga NOA-113 cultivated in a long tubular photobioreactor. J Ferment Bioeng 82: 351-354.

[24] Nagase H, Yoshihara K, Eguchi K, et al. 1997. Characteristics of biological NOx removal from flue gas in a Dunaliella tertiolecta culture system. J Ferment Bioeng 83: 461-465. 
[25] Lee BD, Apel WA, Smith WA 2001. Oxygen effects on thermophilic microbial populations in biofilters treating nitric oxide containing off gas streams, Environ Prog 20: 157-167.

[26] Patureau D, Bernet N, Moletta R 1997. Combined nitrification and denitrification in a single aerated reactor using the aerobic denitrifier Comamonas sp. Strain SQLY2. Water Res 31: 1363-1370.

[27] Patureau D, Zumstein E, Delgenes JP, et a1. 2000. Aerobic denitrifiers isolated from diverse natural and managed ecosystems. Microbial Ecology 39: 145-152.

[28] Okuno K , Hirai M, Sugiyama M, et al. 2000. Microbial removal of nitrogen monoxide (NO) under aerobic conditions. Biotechnol Lett 22: 77-79.

[29] Chung YC, Huang C 1998. Biotreatment of ammonia in air by an immobilized Nitrosomonas europaea biofilter. Environ Prog 17(2): 70-76.

[30] Du Plessis CA, Kinney KA, Schroeder ED, et al. 1998. Denitrification and nitric oxide reduction in an aerobic toluene-treating biofilter. Biotechnol Bioeng 58: 408-415.

[31] Chou MS, Lin JH 2000. Biotrickling filtration of nitric oxide. Jawma 50: 502-508.

[32] Jiang R, Huang SB, Yang J 2008. Biological removal of NOx from simulated flue gas in aerobic biofilter. Global NEST Journal 10(2): 241-248.

[33] Yu AR, Li Y, Yu JA. 2005. Denitrification of a newly isolated Bacillus strainW2 and its application in aquaculture. Journal of Microbiology (in Chinese, with English abstract) 25(3): 77-81.

[34] Young HA 2006. Sustainable nitrogen elimination biotechnologies: A review. Process Biochemistry 41: 1709-1721.

[35] Seung HB, Cheng RY, Sung TL 2001. Aerobic nitrate respiration by a newly isolated phenol-degrading bacterium, Alcaligenes strain P5. Biotech Lett 23(8): 627-630.

[36] Lloyd D 1993. Aerobic denitrification in soils and sediments: from fallacies to facts. Trends Ecol Evol 8: 352-356.

[37] Huang HK and Tseng SK 2001. Nitrate reduction by Citrobacter diversus under aerobic environment. Appl Microbiol Biotechnol 55: 90-94.

[38] Mia K, Seong YJ, Su JY, et al. 2008. Aerobic denitrification of Pseudomonas putida AD-21at different C/N ratios. J Biosci Bioeng 106(5): 498-502.

[39] Joong KK, Kyoung JP, Kyoung SC, et al. 2005. Aerobic nitrification-denitrification by heterotrophic Bacillus strains. Bioresour Technol 96: 1897-1906.

[40] Lesley A, Robertson LA, Kuenen JG. 1983. Thiosphaera pantropha gen. nov. sp. nov., a facultative autotrophic sulphur bacterium. J Gen Microbiol 129: 2847-2855.

[41] Schulp JA, Stouthamer AH 1970. The influence of oxygen, glucose and nitrate upon the formation of nitrate reductase and respiratory system in Bacillus licheniformis. J Gen Microbiol 64: 195-203. 